УДК 93/94:351.81:37.046(477.74)

DOI 10.47049/2226-1893-2020-2-7-28

\title{
ПЕРИПЕТИИ СУДЬБЫ ПРОФЕССОРА ЧАРЛЬЗА КЛАРКА: К ИСТОРИИ «ОДЕССКОГО» ПЕРИОДА ЖИЗНИ
}

\section{В.В. Левченко}

к.ист.н., доцент кафедры

«Украиноведение, историко-правовые и языковые дисциплины»

Одесский национальный морской университет, Украина, Одесса

Г.С. Левченко

к.ист.н., доцент кафедры «История Украины»

Одесский национальный университет им. И.И. Мечникова

\author{
А.Б. Ляшенко \\ к.т.н., профессор, декан факультета \\ судостроения, информационных технологий и системотехники \\ Одесский национальный морской университет, Украина, Одесса
}

Аннотация. В первой части статьи, посвященной профессору Ч.Д. Кларку, указано, что развитие современной науки не обходится без учета существующего наследия предшествующих поколений ученых. В советский период имена многих ученых 1920-х г2., признанные со временем советской властью «буржуазными», были надолго забыты, и до сих пор было мало что известно об их жизни и творчестве. Такая судьба постигла и профессора Ч.Д. Кларка, имя которого как деятеля дореволюиионной и раннего периода советской эпохи было также надолго предано забвению.

Актуальность темы, заключается в том, что анализ большинства аспектов деятельности Ч.Д. Кларка в «одесский» период его жизни дает возможность глубже осмыслить исторические события и явления, раскрыть содержание и спещифику становления и развития высшего судостроительного образования на территории Украины. «Одесский» период жизни Ч.Д. Кларка, его методико-педагогическая, научно-организационная и общественная деятельности до сих пор оставались не изученными, поэтому без сомнения, заслужсивают на специальное научное исследование, которое позволит продемонстрировать вклад этого незаурядного человека в учебно-научные и общественные процессы в Odecce.

(C) Левченко В.В., Левченко Г.С., Ляшенко А.Б., 2020 
ВІСНИК

ОДЕСЬКОГО НАЦІОНАЛЬНОГО

МОРСЬКОГО УНІВЕРСИТЕТУ № 2 (62), 2020
HERALD

OF THE ODESSA NATIONAL

MARITIME UNIVERSITY № 2 (62), 2020

Целью исследования является попытка научной реконструкции деятельности Ч.Д. Кларка в образовательной, научной и общественной плоскостях в «одесский» период его жизни, что дает возможность углубить и расширить наше представление о содержании культурного процесса на рубеже 1910-х-1920-х г2. Задачи исследования определень в соответствии с темой: 1) характеристика «одесского» периода жизни Ч.Д. Кларка; 2) освещуение его педагогической, научной и общественной деятельности; 3) оценка его вклада в развитие высшего судостроительного образования в Одессе; 4) ознакомление с научным наследием и проведение анализа его основных направлений научных исследований.

Ключевые слова: Ч.Д. Кларк, Одеса, судостроение, высшая икола, высшее образование, наука.

УДК 93/94:351.81:37.046(477.74)

DOI 10.33082/2226-1893-2019-2-7-28

\section{ПЕРИПЕТІЇ ДОЛІ ПРОФЕСОРА ЧАРЛЬЗА КЛАРКА: ДО ІСТОРІЇ «ОДЕСЬКОГО» ПЕРІОДУ ЖИТТЯ}

\section{В.В. Левченко}

к.іст.н., доцент кафедри

«Українознавство, історико-правові та мовні дисципліни»

Одеський національний морський університет, Україна, Одеса

Г.С. Левченко

к.іст.н., доцент кафедри «Історія України»

Одеський національний університет ім. I.I. Мечникова

О.Б. Ляшенко

к.т.н., професор, декан факультету

суднобудування, інформаційних технологій і системотехніки

Одеський національний морський університет, Украӥна, Одеса

Анотація. У першій частині статті, присвяченій професору Ч.Д. Кларку, зазначено, щзо розвиток сучасної науки не обходиться без урахування існуючої спадщзини попередніх поколінь вчених. У радянський період імена багатьох вчених 1920-х рр., визнані згодом радянською владою «буржуазними», були надовго забуті, та до сих пір було мало щзо відомо про їх життя $і$ творчість. Така доля спіткала й професора Ч.Д. Кларка, ім'я якого як діяча дореволючійної та раннього періоду радянської епохи було також надовго забуте.

Актуальність теми, яка полягає в тому, щзо аналіз більшості аспектів діяльності Ч.Д. Кларка в «одеський» період його життя дає можливість глибше осмислити історичні подї та явища, розкрити зміст та специфіку становлення і розвитку вищої суднобудівної освіти на теренах Украӥни. «Одеський» період життя Ч.Д. Кларка, його 
методико-педагогічна, науково-організаційна та громадська діяльності до изього часу залишалися не вивченими, тому без сумніву, заслуговують на спеціальне наукове дослідження, яке дозволить продемонструвати внесок иієї непересічної особи в освітньо-наукові та громадські прочеси в Odeci.

Метою дослідження є спроба наукової реконструкиї діяльності Ч.Д. Кларка в освітній, науковій та громадській площинах в "одеський» період його життя, щзо дає можливість поглибити і розширити наше уявлення про зміст культурного прочесу на зламі 1910-х-1920-х рр. Завдання дослідження визначено відповідно до теми: 1) характеристика «одеського» періоду життя Ч.Д. Кларка; 2) висвітлення його педагогічної, наукової та громадської діяльності; 3) очінка його внеску у розвиток вищзої суднобудівної освіти в Одесі; 4) ознайомлення з науковою спадщиною та проведення аналізу його основних напрямів наукових досліджень.

Ключові слова: Ч.Д. Кларк, Одеса, суднобудування, вища школа, вищза освіта, наука.

UDC 93/94:351.81:37.046(477.74)

DOI 10.33082/2226-1893-2019-2-7-28

THE PERIPETIES OF PROFESSOR CHARLES CLARK: TO THE HISTORY OF THE «ODESSA» PERIOD OF LIFE

\author{
V. Levchenko \\ $\mathrm{PhD}$, docent \\ Department of Ukrainian Studies, Historical, Legal and Language Disciplines \\ Odessa National Maritime University, Ukraine, Odessa \\ G. Levchenko \\ $\mathrm{PhD}$, docent Department of History of Ukraine \\ Odessa National University named after I.I. Mechnikov

\section{A. Lyashenko} \\ $\mathrm{PhD}$, professor, Dean \\ of the Faculty of Shipbuilding, Information Technology and System Engineering \\ Odessa National Maritime University, Ukraine, Odessa
}

Abstract. In the first part of the article dedicated to Professor Ch. Clark, it is pointed out that the development of modern science does not do without considering the existing heritage of previous generations of scientistsx. During the Soviet period, the names of many scientists of the 1920s, recognized by the Soviet regime as «bourgeois» over time, were forgotten for a long time, and until now little was known about their life and work. Such a fate befell Professor Ch. Clark, whose name as a leader of the pre-revolutionary and early period of the Soviet era was also forgotten for a long time. 
The relevance of the topic lies in the fact that the analysis of most aspects of Ch. Clarke in the "Odessa» period of his life makes it possible to more deeply comprehend historical events and phenomena, to reveal the content and specifics of the formation and development of higher shipbuilding education on the territory of Ukraine. "Odessa» period of the life of Ch. Clarke, his methodical-pedagogical, scientific-organizational and social activities have not yet been studied, therefore, no doubt, they deserve a special scientific study that will demonstrate the contribution of this extraordinary person to educational, scientific and social processes in Odessa.

The aim of the study is an attempt at scientific reconstruction of the activities of Ch. Clarke in the educational, scientific and social planes during the "Odessa» period of his life, which makes it possible to deepen and expand our understanding of the content of the cultural process at the turn of the 1910s-1920s. Research objectives are defined in accordance with the topic: 1) characteristic of the "Odessa» period of the life of Ch. Clark; 2) coverage of his pedagogical, scientific and social activities; 3) assessment of his contribution to the development of higher shipbuilding education in Odessa; 4) familiarization with the scientific heritage and analysis of its main directions of scientific research.

Keywords: Ch. Clark, Odessa, shipbuilding, high school, higher education, science.

Из истории методико-педагогической и научно-организационной деятельности Ч.Д. Кларка в Одессе. В 1918 г. события Первой мировой войны, двух революций 1917 г. и Гражданской войны на территории бывшей Российской империи привели в Одессу одного из крупнейших европейских ученых в области судостроения первой трети ХX века - профессора Чарльза Джоновича Кларка (1867-1942). В тяжелые годы смутного времени, на протяжении 1918-1923 гг., он взял на себя нелегкие обязанности организации и становления первого политехнического высшего учебного заведения в Одессе - Политехнического института (ОПИ), который стал фундаментом одесской высшей политехнической школы.

Роль профессора Ч.Д. Кларка в создании и формировании методико-педагогической и научно-технической базы ОПИ является одной из главных и определяющих. Эти факторы дают основание для изучения «одесского» периода жизни педагога, ученого, организатора науки, инженера-изобретателя и общественного деятеля, личности которого в советское время и в первые годы постсоветского периода не уделялось должного внимания в публикациях, посвященных истории высшего политехнического образования в Одессе [1-7]. Возвращение имени Ч.Д. Кларка на страницы научной литературы началось лишь в постсоветский период. В последние три десятилетия в контексте изменившихся исторических 
обстоятельств появилась возможность для всестороннего изучения его биографии, в частности «одесского» периода жизни.

На сегодня в литературе существует несколько биографических публикаций справочного формата [8-12], посвященных Ч.Д. Кларку, но до сих пор не написана полная творческая биография ученого, в том числе раскрывающая определенные детали «одесского» периода его жизни. Отдельные сюжеты вклада профессора в развитие высшего политехнического образования в Одессе получили частичное освещение в научных публикациях последних лет [12-14]. В целом можно утверждать, что биография и научное наследие Ч.Д. Кларка отражены в историографии лишь в незначительной степени, однако систематического изучения биографичного портрета ученого до сих пор еще не было осуществлено.

Восполнить имеющиеся пробелы в биографии Ч.Д. Кларка и осуществить попытку реконструкции отдельных фрагментов «одесского» периода его жизни помогают документы фондов Центрального государственного архива высших органов власти и управления Украины (ЦГАВОВ) в Киеве и Государственного архива Одесской области (ГАОО) в Одессе. Наибольшее количество ценных материалов обнаружено и обработано в фонде «Одесского политехнического института» ГАОО, среди которых отдельный интерес вызывают собственноручно подписанные Ч.Д. Кларком автобиография и дополнительные биографические сведения (см. прил. 1), а также письмо Ч.Д. Кларка ректору ОПИ А.А. Нилусу (см. прил. 2). Выявленные уникальные исторические источники позволяют осуществить попытку по-новому представить образ ученого в эпоху смены политических режимов, фрагментарно восстановить повседневные условия деятельности научной корпорации Одессы на рубеже 1910-х-1920-х гг. Документы публикуются на языке оригинала с приведением в соответствии с правилами орфографии и пунктуации современного русского языка. Встречающиеся в текстах документов сокращения слов расшифрованы в квадратных скобках. Все материалы представляют собой рукописные оригиналы с собственноручными подписями авторов.

Можно констатировать, что в последние три десятилетия отмечается устойчивый интерес исследователей истории науки к биографии и научным достижениям Ч.Д. Кларка. Вместе с тем, очевидным является факт недостаточного изучения его общественной деятельности, отсутствуют специальные обобщающие труды, анализирующие научное наследие ученого. Поэтому на основании историографического анализа авторы обосновали необходимость комплексной научной разработки темы. Многогранная и плодотворная образовательно-научная и общественная деятельность известного ученого, несомненно, заслуживает специального исследования. Оно позволит продемонстрировать вклад этого незаурядного человека в развитие общественных и культурных процессов в Одессе в 1918-1923 гг. 
В Южную Пальмиру семья Ч.Д. Кларка прибыла 1 августа 1918 г. в статусе беженцев, как он указывал в собственноручно подписанном 4 апреля 1923 г. «Личном деле» [15, л. 133, 135]. Переезд семьи Ч.Д. Кларка, прожившего более сорока лет в Риге, с берегов Балтийского моря в «столицу» северного побережья Черного моря, было связано с радикальными изменениями геополитической ситуации в Европе. В связи с военными действиями Первой мировой войны в 1915 г. состоялась эвакуация Рижского политехнического института (РПИ), в котором Ч.Д. Кларк работал, начиная с 1 сентября 1899 г. [15, л. 134 об.]. Сначала РПИ был эвакуирован в Москву, а затем в Иваново-Вознесенск, где на его базе осенью 1918 г. был образован Иваново-Вознесенский политехнический институт. Ч.Д. Кларк переехал в Москву вместе со своей большой семьей, в которой было восемь детей. Заболев в феврале 1918 г., он уехал в отпуск из Москвы в Белгород, где на то время находилась его семья. Летом 1918 г. ему было предложено принять участие в организации Политехнического института в Иваново-Вознесенске или Одессе. Вскоре он согласился на должность профессора ОПИ и 1 августа 1918 г. переехал с семьей в Одессу $[15$, л. 135]. Причиной выбора семьей Ч.Д. Кларка из двух городов именно Одессы стало то, что в условиях Гражданской войны, охватившей бывшую Российскую империю после революций 1917 г., массы людей в поисках спасения от опасностей и большей обеспеченности продуктами бежали в южные районы страны, находившиеся тогда еще сравнительно далеко от зоны военных действий и центра революционных катаклизмов. В смутное время 1917-1920 гг. в Одессе беженцы из разных районов страны составляли значительную часть населения, не исключением стала и семья профессора Ч.Д. Кларка.

В Одессе к этому времени сформировалась большая группа научно-технической интеллигенции, стремившейся продолжить деятельность по подготовке высококвалифицированных технических кадров, был образован из числа демобилизованных из армии студентов различных технических вузов Российской империи Одесский «Союз студентов-техников», который вел регистрацию таких студентов и абитуриентов, и занимался их распределением по специальностям и курсам в вузах Одессы. Именно представители «Союза студентов-техников» в своем докладе на собрании инициативной группы общественных деятелей 9 апреля 1918 г. в Одесском отделении Русского технического общества, где обсуждался вопрос об учреждении политехникума, озвучили идею о необходимости создания в Одессе вуза технического профиля: «Так как переживаемые безвременье и развал хозяйственной жизни страны не должны останавливать культурного строительства края, то приходится признать желательным осуществление в Одессе Политехникума в как можно ближайшее время» [8]. Для решения этой задачи важным было желание городских властей Одессы, поддержавших инициативу студентов-техников, открыть Политехнический институт в одном из крупнейших городов страны, который 
являлся научно-образовательным центром и главным портом южного региона, который был бы ориентирован на подготовку технических кадров в контексте промышленного развития страны.

«Союз студентов-техников» обратился к Городской думе с воззванием о необходимости организации в Одессе политехнического института. Инициатива студентов-техников была поддержана Одесским отделением Русского технического общества и городским головой М.В. Брайкевичем, который одновременно будучи председателем Одесского отделения Русского технического общества уже давно вынашивал планы относительно открытия политехникума в Одессе. После принятия летом 1918 г. Городской думой решения об учреждении в Одессе политехнического института при Одесском отделении Русского технического общества был сформирован Организационный комитет из представителей городских властей (кооптированными членами были избраны городской голова, генерал-лейтенант А.С. Санников, помощники городского головы А.Р. Орбинский и А.А. Ярошевский, член городской управы М.И. Пташицкий и управляющий конторой Государственного банка А.А. Молотков), заинтересованных заведений и учреждений и научно-технической интеллигенции. Этот комитет был разбит на четыре комиссии: программно-учебную (35 человек, председатель профессор И.Ю. Тимченко, помощник председателя Ф.С. Бернфельд, секретарь Н.Н. Васильев), организационную (22 человека, председатель Я.С. Балабан, помощник председателя В.А. Бертенсон, секретарь Л.М. Киссер), финансово-хозяйственную (22 человека, председатель М.В. Брайкевич, помощники председателя Г.М. Вольфензон и Б.И. Кондратьев) и по разработке программы экономического отдела (12 человек, председатель профессор С.И. Солнцев), члены которых провели подготовительную работу по организации ОПИ [16, л. 14-15 об.].

Ни в одной из четырех комиссий имя Ч.Д. Кларка не значится. Скорее всего именно летом 1918 г. имеющий более двадцати лет опыта преподавания и научно-практической деятельности в области высшего технического образования Ч.Д. Кларк был приглашен к участию в организации, становлении и развитии инфраструктуры ОПИ. Кто из членов Организационного комитета выходил на связь, вел переговоры и сыграл главную роль в приглашении Ч.Д. Кларка в Одессу на сегодня установить не удалось. Но точным и однозначным фактом остается то, что с первых дней после приезда 1 августа 1918 г. в Одессу он принимал непосредственное деятельное участие в организации инфраструктуры ОПИ [15, л. 135]. Так, из письма профессора Ч.Д. Кларка к ректору ОПИ А.А. Нилусу от 17 августа 1918 г. узнаем, что уже 16 августа, чуть более чем после двух недель после приезда в Одессу, погрузился в ежедневную кропотливую работу: «Вчера вечером заседали мы по вопросу распределений занятий между преподавателями» (см. П. 2). 
В сжатые сроки на протяжении августа 1918 г. Организационный комитет разработал «Устав Одесского политехнического института», в котором была определена его структура и указывалось, что управление институтом возлагается на Попечительный совет, Совет института, Технический комитет, факультетские собрания, ректора и проректора института. В уставе также был определен состав этих органов, порядок их избрания и их компетенции. «Союз студентов-техников» предварительно провел регистрацию абитуриентов и студентов и распределил их по специальностям и курсам. Во время комплектования студенческого контингента предпочтение отдавалось выпускникам (или бывшим студентам) средних и высших учебных заведений технического профиля (студенты физико-математических факультетов принимались в последнюю очередь) [17, л. 4-5 об.]. Последний фактор свидетельствует о намерениях организаторов вуза вести подготовку именно техников-практиков для различных отраслей промышленного хозяйства.

С первых дней пребывания в Одессе Ч.Д. Кларк был включен в состав Попечительного совета, Президиума Организационного комитета и Совета института $[16$, л. $1-2,16,18]$ - три главных руководящих органа в организации и становлении ОПИ. В Попечительном совете, состоящем из 17 человек, Ч.Д. Кларк сотрудничал вместе с Я.С. Балабаном, К.Р. Кропусковым, А.А. Нилусом, И.Ю. Тимченко, В.Н. Твердохлебовым, Л.И. Мандельштамом, В.Д. Ласкаревым, Г.Г. Швитау, М.В. Брайкевичем, Г.М. Вольфензоном, В.И. Алымовым, Б.И. Кондратьевым, Ф.С. Бернфельдом, А.М. Левицким, И.В. Серебренниковым и Л.И. Спиваковым (последние трое были студентами) [16, л. 1]. В Президиум Организационного комитета по учреждению ОПИ, включающем 16 человек, Ч.Д. Кларк вошел вместе с М.В. Брайкевичем, Б.И. Кондратьевым, В.И. Алымовым, Н.Н. Васильевым, В.А. Бертенсоном, Г.М. Вольфензоном, Ф.С. Бернфельдом, Я.С. Балабаном, И.Ю. Тимченко, Л.М. Киссером, А.А. Нилусом, В.Н. Твердохлебовым, А.П. Фан-дер-Флитом, С.Д. Левенсоном и Р.А. Рейхенбергом (последние двое были из числа студентов) [16, л. 2]. Заседания Президиума Организационного комитета по созданию ОПИ в период с июля по ноябрь 1918 г. проходили в помещении Военнопромышленного комитета (организация российских предпринимателей, созданная с целью мобилизации промышленности для военных нужд в период Первой мировой войны), расположенного по адресу, улица Пушкинская, 11 [16, л. 3-5, 20]. На первое собрание Совета ОПИ, которое состоялось в субботу 8 сентября 1918 г. в пять часов дня Ч.Д. Кларка лично пригласил ректор А.А. Нилус (см. П. 3).

Принимая активное участие в работе трех инструктивных органов по организации и развитию инфраструктуры ОПИ в период с августа по сентябрь 1918 г., Ч.Д. Кларк лично занимался разработкой учебных программ по основным инженерным дисциплинам и учебных планов для всех факультетов института, проводил набор преподавателей для новых 
дисциплин, курировал налаживание образовательного процесса, стоял у истоков создания двух факультетов - механического и инженерностроительного, в частности способствовал становлению и развитию специальностей судостроения и судовой механики, и всячески ратовал за техническое развитие института.

За разработку и составление учебных планов для всех факультетов вуза в сентябре 1918 г. Ч.Д. Кларку к месячному окладу профессора (700 руб., годовой оклад 8400 руб.) и занимание должности декана (150 руб., годовой оклад 1800 руб.) была выписана дополнительная сумма в размеpe 850 руб., что в целом составило месячный оклад в размере 1700 руб. Подобная сумма заработной платы была самой высокой в ОПИ, даже по сравнению с месячным жалованием ректора А.А. Нилуса, который равнялся 1250 руб. [18, л. 4].

В результате практически двухмесячной работы по подготовке 15 сентября 1918 г. Одесским отделением Русского технического общества совместно с целым рядом общественных организаций был учрежден ОПИ $[17$, л. 1]. Торжественное официальное открытие ОПИ и начало первых лекций произошло три дня спустя - 18 сентября. В связи с этим событием в газете «Одесский листок» появилось сообщение о том, что в здании Русского Технического общества (ул. Новосельского, 4) произошло знаменательное событие - торжественное открытие Одесского политехнического института: «начинает свою жизнь долгожданный и необходимый для развития промышленности юга страны институт» [19].

На момент открытия ОПИ состоял из трех факультетов: механического с электротехническим, судостроительным и механическим (промышленное машиностроение и технологии металлов и дерева) отделениями; инженерно-строительного с отделениями сухопутно-дорожного строительства, мелиоративно-гидротехническим и санитарного зодчества; экономического с публично-хозяйственным и частно-хозяйственным отделениями. Каждое отделение, в свою очередь, распределялось на несколько направлений с целью подготовки специалистов в соответствующих областях. Методика обучения предусматривала избрание студентом одного из направлений, постепенно концентрируя свое внимание и интерес на одном узком кругу вопросов в области выбранной им отрасли науки. Главным тезисом, который формулировал линию обучения студентов в ОПИ был: «От общего к частному, от широкого к узкому, от подчиненной работы к самостоятельному труду» [17, л. 1-1 об.].

В открытом 15 сентября 1918 г. ОПИ Ч.Д. Кларк вошел в его преподавательский штат - став профессором кафедр судостроения и прикладной механики механического факультета. Был избран деканом механического факультета и и. о. декана инженерно-строительного факультета, $[20$, л. 1, 5]. Деканом механического факультета он оставался на протяжении 1918-1923 гг., а обязанности и.о. декана инженерно-строительного факультета исполнял до 1920 г. В сентябре 1918 г. Ч.Д. Кларк 
взял на себя ответственность заведывания гидравлической лабораторией [18, л. 10], а по состоянию на 29 апреля 1921 г. также являлся заведующим машинно-котельной станции [21, л. 20-21, 38]. В весеннем семестре 1920 г. Ч.Д. Кларк был профессором кафедр гидравлики и судостроения, заведовал гидравлической машинной лабораторией и занимал две выборные должности - декан механического факультета и член Правления института [22, л. 11, 15]. По состоянию на октябрь 1921 г. Ч.Д. Кларк заведовал кафедрой теплотехники. В разные годы его ассистентами как профессора этой кафедры последовательно были Л.А. Длугоканский (1918-1920) [18, л. 1], В.П. Гаузенберг (1920-1921) и Д.И. Рабинович (1921-1923) [23, л. 187].

Во время работы в ОПИ профессор Ч.Д. Кларк принимал непосредственное участие в формировании и становлении подготовки в вузе специалистов судостроения и судовой механики. Если наличие первой из них было предусмотрено в институте начиная с 1918 г., то вторую - было введено начиная с 1920 г., когда на механическом факультете было основано судомеханическое отделения. Соответственно в 1920/21 учебном году начали преподавать специальные дисциплины по данной отрасли знания. Так, профессор Ч.Д. Кларк на этом отделении вел лекции по введению в машиностроение, гидравлической теории передачи тепла, общему курсу гидротехнических и гидравлических двигателей, общему курсу паровых котлов, теории сопротивления судов, основам и определению форм и размеров судов, теории гребных винтов и колес, центробежных насосов судов, паровым котлам [24, л. 8 об.].

По состоянию на 4 апреля 1923 г. Ч.Д. Кларк работал по специальностям - теплотехника, гидротехника и судостроение. Вел лекции и практические занятия по курсам: введение в машиностроение, теория передачи тепла, гидравлике, паровые котлы, гидротехнические сооружения, гидравлические двигатели, центробежные насосы, дополнительные главы по гидравлическим двигателям, теория корабля, корабельная архитектура, вибрация судов, судовые механизмы, строительная механика корабля, основы определения форм и главных размеров судов, теории сопротивления судов, теории гребных винтов и колес, проектирование гидравлических двигателей и центробежных насосов, проектирование паровых котлов, проектирование судов и руководство дипломными проектами $[15$, л. 133,138$]$.

За все время преподавания в ОПИ Ч.Д. Кларк читал лекции по большому количеству курсов - гидравлика, гидротехнические сооружения, гидравлические двигатели, центробежные насосы, теоретическая передача тепла и горения, паровые котлы, теория корабля, корабельная архитектура, вибрация судов, судовые механизмы, строительная механика корабля, проектирование гидравлических двигателей и центробежных насосов, проектирование паровых котлов, проектирование судов основы определения форм и главных размеров судов, теория сопротивления 
судов, теория гребных винтов и колес, введение в машиностроение и др. Из перечисленных дисциплин многие из них лично были введены профессором впервые: введение в машиностроение, теория передачи тепла, основы определения форм и главных размеров судов [15, л. 135 об.-136]. Из курса паровых котлов Ч.Д. Кларк выделил раздел «Теплопередача», который впервые в СССР читал как самостоятельную дисциплину $[2$, c. 36$]$.

На протяжении всего времени работы в ОПИ у Ч.Д. Кларка индивидуальная преподавательская нагрузка всегда была самой большой, которая в среднем составляла от 18 до 22 часов в неделю [15, л. 138]. Например, в весеннем семестре 1920 г. Ч.Д. Кларк выполнял нагрузку в размере 27,5 часов в неделю. Среди преподавательского состава подобные нагрузки были у незначительного числа коллег: у старшего преподавателя кафедры прикладной механики А.А. Курсина - 20,5 часов, младшего преподавателя кафедры математики Н.Э. Бомовского - 20 часов, младшего преподавателя кафедры строительной механики Н.Н. Зарембо-Влодычанского и доцента кафедры физики Н.Д. Папалекси - 18,5 часов. У других преподавателей нагрузка была 18 и менее 18 часов в неделю. Стоит отметить, что большая нагрузка была и у представителей вспомогательного персонала кафедр (лаборантов, препараторов и ассистентов). Так, у лаборанта кафедры физики К.Б. Романюка - 36 часов в неделю, у лаборантов кафедры машиностроения И.С. Брейтбурта, С.Д. Левенсона и Р.А. Рейхенберга, помощника лаборанта кафедры физики Д.Ч. Кларка, препаратора кафедры химии Н.Ф. Кульчевича, ассистента кафедры геодезии Д.В. Пясковского, лаборанта кафедры электротехники С.С. Хинкуса и ассистента кафедры физики Б.Ф. Цомакиона нагрузка в неделю составляла по 24 часа [22, л. 11-11 об.].

Работая в ОПИ, Ч.Д. Кларк много времени уделял методической работе. Он был председателем судостроительной и механической предметных и технических комиссий $[15$, л. 138]. Предметные комиссии проводили учебно-методическую работу, формировались из числа ведущих специалистов и активной части студенчества факультета для направления и координации разработки учебных планов и программ. Деятельность всех предметных комиссий на факультетах координировали факультетские комиссии, на которые возлагались распределение учебного плана и специализации по факультетам. На основе «Кодекса законов о народном образовании» 1923 г. во всех вузах УССР должны были быть созданы предметные комиссии, задачей которых были подготовка педагогических кадров, разработка учебных планов, новых методов преподавания, форм учета знаний, умений и навыков студентов. Председатели предметных комиссий вносили конкретные предложения для улучшения учебных планов. Количество предметных комиссий на одном факультете определяла факультетская комиссия [25]. Предметные комиссии оказывали помощь во внедрении новых методов обучения, усовершенствовании 
программ и рабочих планов, создании учебно-вспомогательных учреждений и т. п. [26, с. 218-220].

За все время работы в ОПИ Ч.Д. Кларк стоял у истоков высшего технического образования в Одессе и в целом в УССР. Лично проводил набор преподавателей на новые дисциплины, разрабатывал учебные программы и планы, курировал образовательным процессом и всячески ратовал за техническое развитие института. Отобранный им преподавательский состав был очень высокого профессионального уровня. Вместе с коллегами (В.И. Алымов, С.Т. Каменский, М.И. Михайлов и др.) профессор Ч.Д. Кларк заложил основы судостроительной и судомеханической специальностей, на базе которых в 1923 г., уже после его отъезда, был создан судостроительный факультет, на базе которого в 1930 г. был создан Одесский институт инженеров водного транспорта, который на сегодня является Одесским национальным морским университетом.

Параллельно с педагогической деятельностью Ч.Д. Кларк проводил активную научную работу в области гидротехники, гидравлических двигателей, теории передачи тепла и горения, паровых котлов, основ определения форм и главных размеров судов, сопротивления судов, теории гребных винтов и колес, по вопросам расходования пара в паровых машинах и паровых турбинах, водоструйных, пароструйных и воздухоструйных аппаратов. Напечатал труды «О влиянии носовых углов на сопротивление судна», «Расчет турбины Francisa», «О призвании инженер-механика», «Реорганизация теплового хозяйства и переустройство силовых станций прокатного завода» и др. Кроме того он также написал ряд работ для различных заводов в области гидротехники, теплотехники и судостроения, но в силу определенных обстоятельств они не были опубликованы [15, л. 135 об.-136].

Пребывая в Одессе, Ч.Д. Кларк также проявил себя как талантливый организатор науки. 28 декабря 1921 г. он был избран председателем (заместитель - профессор, математик В.Ф. Каган) Научного бюро Одесского губернского комитета профессионально-технического и специально-научного образования - постоянного органа, утверждённого для разработки планов и структуры формирующихся самостоятельных научно-исследовательских учреждений независимо от вузов, которые должны были объединить все имеющиеся в Одессе научные силы, независимо от их ведомственного подчинения и постоянного места работы. Активная работа Научного бюро по организации научно-исследовательских кафедр была начата зимой 1922 г. Его членами кроме Ч.Д. Кларка и В.Ф. Кагана также являлись другие известные ученые ведущих одесских вузов: правовед Э.Я. Немировский (научный секретарь), математик и механик И.Ю. Тимченко, математик С.О. Шатуновский. Согласно резолюциям, полученным из НКП УССР относительно вопросов организации научноисследовательских кафедр в Одессе можно было основать лишь 15 подобных учреждений, но при каждом из них могло состоять столько сек- 
ВІСНИК

ОДЕСЬКОГО НАЦІОНАЛЬНОГО

МОРСЬКОГО УНІВЕРСИТЕТУ № 2 (62), 2020
HERALD

OF THE ODESSA NATIONAL

MARITIME UNIVERSITY № 2 (62), 2020

ций, сколько это кажется необходимым в соответствии с местными научными силами, не превышая общей численности 5-6 сотрудников. Научное бюро разработало общие основания, в соответствии с которыми были установлены кафедры и выбраны их руководители. После одобрения Коллегией Одесского губернского комитета профессионально-технического и специально-научного образования этого списка, на заседание Научного бюро по очереди приглашались руководители и вместе с ними кафедры делились на секции и избирались их заведующие. Затем в заседаниях, в которых принимали участие все заведующие секций, проводился отбор персонала каждой секции и кафедры. В решении вопроса организации научно-исследовательской кафедры учитывались два главных момента: важность научной дисциплины и наличие в Одессе лица, которое могло поставить научное исследование в этой области на высокий уровень. При одинаковой важности различных дисциплин Научное бюро останавливало свой выбор на той области знаний, которая по наличию научных сотрудников в городе могла бы рассчитывать на более широкие результаты научного исследования. Таким образом, представленный план являлся результатом совместной работы ученых Одессы и Научного бюро во главе с Ч.Д. Кларком [27, с. 210-211].

В результате сложных выборных процессов к началу 1922/23 учебного года Научное бюро сформировало 13 научно-исследовательских кафедр: математики (4 секции, руководитель И.Ю. Тимченко); физики (4 секции, руководитель Л.И. Мандельштам); биологии (5 секций, руководитель Ф.М. Породко); географии и геогнозии (3 секции, руководитель Г.И. Танфильев); химии (3 секции, руководитель П.И. Петренко-Критченко); морфологии и физиологии (4 секции, руководитель В.В. Во-ронин); экспериментальной и социальной медицины (7 секций, руководитель В.П. Филатов); прикладной механики (5 секций, руководитель Ч.Д. Кларк); инженерностроительных наук (4 секции, руководитель В.И. Зуев); агрономии (3 секции, руководитель А.А. Браунер); правовых наук и прикладной экономики (5 секций, руководитель А.Я. Шпаков); истории культуры и археологии (3 секции, руководитель Б.В. Варнеке); языкознания и литературы (руководитель А.И. Томсон) [28, л. 29]. В таком формате научно-исследовательские кафедры просуществовали на протяжении 1922/23 учебного года, а в начале следующего учебного года, когда состоялся отъезд Ч.Д. Кларка из Одессы, произошла очередная трансформация их структуры.

Руководящее участие Ч.Д. Кларка в формировании инфраструктуры научно-исследовательских учреждений в Одессе привело не только к организации и продолжению деятельности многих специалистов в разных областях знания, но и предоставила ему возможность познакомиться и сотрудничать со многими видными учеными - А.А. Браунер, Б.В. Варнеке, П.И. ПетренкоКритченко, А.И. Томсон, В.П. Филатов и др. Научно-организационная деятельность Ч.Д. Кларка в Одессе в начале 1920-х гг. является частью определенного этапа в подготовке и воспитании научных кадров и преподавателей вузов, в развитии науки в УССР. 
Приложения

Приложение 1

\title{
Автобиография и дополнительные сведения Ч.Д. Кларка от 4 апреля 1923 г. [15, л. 134-137 об.]
}

\author{
Curriculum vitae \\ профессора Одесского политехнического института \\ Чарльза Джоновича Кларка
}

Сын профессора Рижского политехнического института Джона Чарльзовича Кларка, академика Академии художеств в Петрограде, воспитанного в Лондоне.

Родился я в Риге в 1867 году.

В 1894 г. окончил курс Рижск[ого] политехн[ического] инст[итута] с отличием и получил звание инженер-технолога, поступил на верфь «Ланге и сын» в качестве инженера Технического бюро.

В 1896-97 гг. занимался я заграницей по своей специальности, получив командировку от упомянутой верфи и от Технического общества гор[ода] Риги.

В 1897 г. я представил свой отчет.

В 1897 г. я был командирован Мин[истерством] нар[одного] просв[ещения] за границу для подготовки к преподавательской деятельности и на заводы России, о чем представил свой отчет.

Весной 1898 г. я был назначен главным инженером верфи «Ланге и сын».

28 июля 1898 г. по предложению факультета и уч[ебного] округа после чтения пробной лекции по «Техническим измерениям» я был утвержден доцентом Р[ижского] П[олитехнического] И[нститута] по прикладной механике с поручением чтения «Технич[еских] измерений» и «Термодинамики».

30 декабря 1899 г. я был утвержден адъюнкт-профессором по прикладной механике с 1 сент[ября] 1899 года.

6 ноября 1902 г. по представлению Совета Р[ижского] Политехнического] И[нститута] научных работ по «Гидравлическим двигателям» и «Паровым котлам» был избран Советом и утвержден М[инистерством] Н[ародного] П[росвещения] ординарным профессором при Р[ижском] у[чебном] о[круге] с 1 июля 1902 года.

В 1905 г. я был командирован в Данциг для ознакомления с судостроит[ельным] факультетом при Высшем технич[еском] инст[итуте] в Данциге.

С 8 мая 1906 г. по предложению факультета я был утвержден в должности декана мех[анического] фак[ультета], считая эту должность с 8 октября 1905 г. 
По предложению Р[ижского] уч[ебного] окр[уга] от 30.ІІІ.13 я был командирован в С[анкт]-Петербург на время с 17 по 27 апреля 1913 г. для принятия участия в съезде по горному делу, металлургии и машиностроению.

Кроме того, я был командирован в Петроград на 2 месяца в качестве представителя Р[ижского] П[олитехнического] И[нститута] для участия в разработке устава Высшей технической школы.

Деканом мех[анического] фак[ультета] я состоял от 8 окт[ября] 1905 г. до февраля 1918 г.

Заболев в феврале 1918 года, я уехал из Москвы, куда Р[ижский] П[олитехнический] И[нститут] был эвакуирован в отпуск в гор[од] Белгород к семье и оказался отрезанным от Москвы.

К осени 1918 г. мне было предложено принять участие в организации Политехнич[еского] инст[итута] в Иваново-Вознесенске и в Одессе. Я согласился на должность профессора О[десского] п[олитехнического] и[нститута] и приехал с семьей в Одессу 1 авг[уста] 1918 г.

После приезда в Од[есский] п[олитехнический] инст[итут] был я избран факультетом деканом мех[анического] и стр[оительного] фак[ультет]ов. Деканом мех[анического] фак[ультета] состою я до сих пор. Деканом стр[оительного] фак[ультета] я состоял до осени 1920 г., до выбора про$\phi$ [ессора] Б.Н. Кандибы на эту должность с открытием старших курсов.

С 1 авг[уста] 1918 г. я принимал участие в организации О[десского] П[олитехнического] И[нститута].

В Р[ижском] П[олитехническом] И[нституте] я читал: термодинамику, техн[ические] измерения, гидравлику, гидротехнику, гидравлические двигатели, паровые котлы, пар[овые] турбины, судостроение и руководил дипломным проектированием.

В О[десском] П[олитехническом] И[нституте] я читаю гидравлику, гидротехнические сооруж[ения], гидр[авлические] двигатели, центроб[ежные] насосы, теор[етические] передачи тепла и горения, паровые котлы, основы определения форм и главн[ых] размеров судов, теория сопротивления судов, теория гребн[ых] винтов и колес, введ[ение] в машиностроение и руковожу дипломными проектами.

Из перечисленных предметов мною введены: введение в машиностроение, теория передачи тепла, основы определения форм и главных размеров судов.

Научной работой я занимался в области гидротехники, гидр[авлических] двиг[ателей], теории передачи тепла и горения и паровых котлов, основ определ[ения] форм и гл[авных] размеров судов, сопрот[ивления] судов, теор[ии] гребн[ых] винтов и колес и по вопросам расхода пара в паров[ых] маш[инах] и пар[овых] турб[инах], водоструйн[ых], пароструйных и воздухостр[уйных] аппаратов.

Отпечатаны мои работы «О влиянии носовых углов на сопротивление судна», «Расчет турбины Francisa», «О призвании инженер-механика», «Реорганизация теплового хозяйства и переустройство силовых станций прокатного завода» бывш[его] «Бекер и $\mathrm{K}^{0} »$ в Либаве, доклад в Техническом обществе г. Риги в его журнале «Об устройстве и расчете морского ледокола 
«Петр Великий», заказанного биржевым комитетом и правительством и проектированного и устроенного под моим руководством и др. Кроме того ряд работ, напечатанных для заводов, но неопубликованных и манускрипты по разным вопросам из области гидротехники, теплотехники и судостроения. По постановлению съезда по горному делу, металлургии и машиностроению готовился к печати прочитанный мною на съезде доклад о моей теории расчета котлов.

\section{Практический стаж}

Будучи студентом, я служил 2 года в конторе конструктором Техн[ического] бюро на турбинном заводе «Пирвиц и $\mathrm{K}^{0} »$ в Риге, на верфи акщ[ионерного] общ[ества] «Ланге и сын» я служил с 1894 до 1914 г., с 1898 г. в должности главного инженера. В 1910-1914 г. состоял технич[еским] руководителем турбинного завода «Медеч и $\mathrm{K}^{\circ}{ }^{\circ}$ в Риге. С момента возникновения общества для надзора за пар[овыми] котлами до эвакуации из Риги состоял членом Техн[ического] совета этого общества. Состоял ряд лет консультантом Биржевого комитета и Городской управы гор[ода] Риги и постоянным консультантом заводов «Гартман и $\mathrm{K}^{\circ}$ », «Вольфшмидт и $\mathrm{K}^{0} »$, Сормовского завода, Московского завода «Гунсон», «Бекер и $\mathrm{K}^{\circ} »$ в Либаве, Островецких, Мальцевских, «Rheinische», «Drahtindustrie», «Фельдер и $\mathrm{K}^{0} »$ и других.

В Одессе я состоял председателем Технического совещания Общества для классификации судов «Русскласс», председателем Комиссии по электрификации юга при Технич[еском] обществе, председателем Технического совета при Совнархозе, членом Топкома и др[угих].

В настоящее время состою членом Высшего технического совета при Губкоммунотделе, председателем Научного бюро при Губпрофобре.

\section{Дополнительные сведения}

1. Основная профессия и специальность. Судостроение.

2. Ск[олько] лет работает и на каком поприще. 28 лет на поприще научно-педагогическом и техническом в области судостроения, теплотехники и гидротехники.

3. Какой специальности желает себя посвятить и что сделал в научной области. Желаю посвятить себя научной работе в указанных областях, по которым я все время работал.

4. Знает ли иностр[анные] яз[ыки] и какие именно. Английский, немецкий, латышский.

5. Имеет ли общ[ий] революц[ионный] стаж и какой именно. Не имею.

6. Отношение к воинской повинности. Не служил.

7. Национальность. Великобританская.

8. Возраст. 56 лет.

9. Состоит ли членом профсоюза (№ билета). Почетный член Пленума Губпрофсовета. 
10. Состоит ли членом партии, какой именно (№ билета). Не состою.

11. Положение семейное и имущественное. На моем иждивении находятся жена, 2 сына, 3 дочери (всего 7 членов семьи). Имуществ не имею; беженец.

Профессор ОПИ

Ч. Кларк [подпись]

Приложение 2

\title{
Письмо профессора Ч.Д. Кларка к ректору ОПИ А.А. Нилусу от 17 августа 1918 г. [29, л. 13-15]
}

17 августа 1918 г[од]

\author{
Глубокоуважаемый \\ Андрей Александрович!
}

Вчера вечером заседали мы по вопросу о распределении занятий между преподавателями. Около 9 ч[асов] зашел Феодор Абрамович. Новый план был у меня. Я сообщил ему о наших желаниях. Он согласился на почти все и готов все немедленно переделать. Он надеется, что устроит профессора Л.И. Мандельштама в тех помещениях, которые он предпочитает, что будет в состоянии устроить ему маленькую мастерскую рядом с ученическими помещениями, что вход в ученическую аудиторию устроит по мостику. Он согласился передвинуть немного стену между аудиториями I и II (100 ч[еловек]), указал на то, что он смог бы устроить еще профессорскую одну комнату, но очень просил оставить среднюю аудиторию, нынешнюю для 200 ч[еловек] между 2 профессорскими комнатами так, как он ее спроектировал именно слишком короткой. Он не хотел бы ломать стены, надеется, что полного комплекта слушателей не будет, и обещает, если нужно, то выкинут эту стену в одно воскресенье.

Я не согласился ввиду того, что аудитория, в которой поместятся не 200, но только около 160 недостаточна, и что равенство 3 аудиторий по 200 человек принципиально желательно, с другой же стороны ввиду того, что всякая работа, которая должна быть исполнена стоит нам гораздо дешевле теперь, нежели потом, не говоря о неудобствах. Но если все прочее хорошо устроено, то думаю, что мы придем к соглашению с архитектором и относительно этого вопроса. Для ускорения дела передал я ему вчера план и просил его от Вашего имени переделать, что нужно и возможно в самом непродолжительном времени. Я надеюсь, уже сегодня или завтра пошлет Вам исправленный план, и что Вы согласитесь с тем, что я сделал. 
Сегодня буду я в 10 ч[асов] в канцелярии. В 1/2 11 уедем мы Алексей Алексеевич [Копылов], Александр Гасистович, я и Соломон Данилович [Левенсон] для рассмотрения моделей для технического черчения и деталей машин. Я извиняюсь, если не смогу быть к 12 часам в канцелярии, но дело спешное и я хотел бы присутствовать при выборе.

Не будучи в состоянии, быть сегодня утром в канцелярии, я лишаюсь возможности лично устроить с Михаилом Васильевичем [Брайкевич] свое дело касательно необходимого для моей квартиры тока. Я уже целую неделю сижу без освещения, хотя проводка уже почти закончена. Я очень извиняюсь, что беспокою Вас своим личным делом, но очень просил бы Вас, если Ваше время Вам позволит, переговорить сегодня утром с Михаилом Васильевичем по поводу этого дела ввиду того, что 2 дня подряд праздники.

Я обратился вчера к Михаилу Васильевичу с просьбой устроить мне возможно скорое получения тока, выключенного электрической станцией ввиду съезда с квартиры прежних нанимателей. Михаил Васильевич очень любезно дал вчера распоряжения ходатайствовать для меня о включении тока, но, к сожалению, вчера монтера электрической станции не было.

Боясь, что он, быть может и сегодня не придет, и что я останусь без освещения еще до среды, и не будучи в состоянии предпринять сам что-нибудь сегодня, с другой же стороны очень нуждаюсь в вечернем освещении для срочной работы по Политехникуму.

Я очень извиняюсь, что беспокою Вас своей просьбою, за исполнение которой я был бы очень, очень Вам благодарен.

Мой нижайший привет Вашей глубокоуважаемой супруге.

С глубоким уважением искренне преданный Вам

Чарльз Джонович Кларк [подпись]

Приложение 3

Приглашение Ч.Д. Кларку от ректора ОПИ А.А. Нилуса принять участие в первом собрании Совета ОПИ [17, л. 7]

\author{
Милостивый государь \\ Чарльз Джонович,
}

ректор Одесского политехнического института, свидетельствуя Вам свое совершенное почтение, покорнейше просит Вас пожаловать на первое собрание Совета Института в субботу, 8-го сего сентября, в 5 часов дня, Пушкинская 11.

Предмет суждения:

1/ выборы представителей Совета Института в Попечительный совет по одному от каждого факультета (§ 49 устава Института). 
ВІСНИК

ОДЕСЬКОГО НАЦІОНАЛЬНОГО

МОРСЬКОГО УНІВЕРСИТЕТУ

№ 2 (62), 2020
HERALD

OF THE ODESSA NATIONAL

MARITIME UNIVERSITY № 2 (62), 2020

2/ установление научного ценза преподавателей иностранных языков, черчения, рисования и пр.

3/ составление правил для пользования библиотекой и учебными коллекциями /§ 62/.

С почтением и преданностью

ректор Политехнического института

\section{СПИСОК ЛІТЕРАТУРИ}

1. Рабинович Д.И. 45-летие ОПИ (1918-1963). История возникновения и развития Одесского политехнического института: краткий исторический очерк. Одесса, 1963. С. 2-3.

2. Одесский политехнический институт. Краткий исторический очерк (1918-1968). Киев: Издательство Киевского университета, 1968. $224 \mathrm{c}$.

3. Одесский институт инженеров морского флота. 50 лет. М.: ЦРИА «Морфлот», 1980. $52 \mathrm{c}$.

4. Чарльз Джонович Кларк (1867-1942) // Очерки педагогической и научной деятельности ученых периода становления инстиmута (1918-1930 г2.). Одесса, 1984. C. 33-41.

5. Кузнииа инженерных кадров для морского флота (Краткий исторический очерк). Одесса, 1990. 152 c.

6. Мошнянский А. Звезда по имени ОИИМФ. Изд. 2-е, доп. Одесса: "Acтропринт», 2001. 200 c.

7. Одесский национальный морской университет: История. Люди. Современность: 1930-2005. Одесса: «Астропринт», 2005. $216 \mathrm{c}$.

8. Малахов В.П. Одесский государственный политехнический университет // Очерки развития науки в Одессе / Отв. ред. С.А. Андронати. Одесса: Титул, 1995. С. 375-376.

9. Кларк Чарльз Джонович // История Одесского политехнического в очерках / Ю.С. Денисов, В.И. Бондарь; под ред. В.П. Малахова. Одесса: Астропринт, 2000. С. 35-38.

10. Кларк Чарльз Джсонвич // История Одесского политехнического в очерках: 1918-2003 / Ю.С. Денисов, В.И. Бондарь; ред. В.П. Малахов. Одесса: Астропринт, 2003. С. 47-50.

11. Рікун I.Е. Кларк Чарльз Джонович // Енциклопедія сучасної Украӥни. Т. 13: Киї-Кок. К., 2013. С. 268. 
ВІСНИК

ОДЕСЬКОГО НАЦІОНАЛЬНОГО

МОРСЬКОГО УНІВЕРСИТЕТУ

№ 2 (62), 2020
HERALD

OF THE ODESSA NATIONAL

MARITIME UNIVERSITY

№ 2 (62), 2020

12. Левченко В.В., Гривківська А.О., Шаталова Г.С. Професор Ч.Д. Кларк - основоположник вищої політехнічної освіти в Одесі // Збірник праць ХVI Міжнародної молодіжної науковопрактичної конферениії «Історія розвитку науки, техніки та освіти», присвяченої 120-річчю Начіонального технічного університету Украӥни "Київський політехнічний інститут імені Ігоря Сікорського». Київ, 19 квітня 2018 р. / Укладач Л.П. Пономаренко. Київ, 2018. С. 21-23.

13. Левченко В.В. Розвиток мережі науково-дослідних установ Одеси в 1920-х роках // Наукові прачі історичного факультету Запорізького національного університету. Запоріжжя, 2010. Bun. XXVIII. C. 208-212.

14. Левченко В.В. Из истории истоков становления и развития высшего морского образования в Одессе в первой половине XX века // Вісник Одеського начіонального морського університету: 3б. наук. пращь. Bun. 1 (58). Одеса, 2019. C. 249-265.

15. ГАOO, ф. P-126, on. 1, д. 142.

16. ГАOО, ф. P-126, on. 1, д. 9.

17. ГАOO, ф. P-126, on. 1, d. 4.

18. ГАОО, ф. P-126, on. 1, d. 15.

19. Одесский листок, 1918, 19 сентября.

20. ГАОО, ф. P-126, on. 1, д. 11.

21. ГAOO, ф. P-126, on. 1, д. 129.

22. ГАOО, ф. P-126, on. $1, \partial .107$.

23. ГАOО, ф. P-126, on. $1, \partial .143$.

24. ГАOO, ф. P-126, on. 1, д. 112.

25. Вища школа Украӥнської РСР за 50 років (1917-1967 рр.): історичний нарис: у 2 ч. Ч. 1 (1917-1945 pp.). К., 1967. C. 117.

26. Левченко В.В. Історія Одеського інституту народної освіти (1920-1930 рр.): позитивний досвід невдалого експерименту / Відn. ред. В.М. Хмарський; наук. ред. Т.М. Попова. Одеса: TEC, 2010. $428 \mathrm{c}$.

27. Левченко В.В. Розвиток мережі науково-дослідних установ Одеси в 1920-х роках // Наукові праиі історичного факультету Запорізького національного університету. Запоріжжя, 2010. Bun. XXVIII. C. 208-212.

28. ЦГАВОВ, ф. 166, on. 2, d. 465.

29. ГАOO, ф. P-126, on. 1, d. 16. 


\section{REFERENCES}

1. Rabinovich, D.I. (1963) 45-letie OPI (1918-1963). Istoriya vozniknoveniya i razvitiya Odesskogo politekhnicheskogo instituta: kratkij istoricheskij ocherk. Odessa, pp. 2-3.

2. Odesskij politekhnicheskij institut. Kratkij istoricheskij ocherk (1918-1968). Kiev: Izdatel'stvo Kievskogo universiteta, 1968. (in Russian).

3. Odesskij institut inzhenerov morskogo flota. 50 let. Moskva: CRIA "Morflot», 1980. (in Russian).

4. CHarl'z Dzhonovich Klark (1867-1942). Ocherki pedagogicheskoj $i$ nauchnoj deyatel'nosti uchenyh perioda stanovleniya instituta (1918-1930 gg.). Odessa, 1984, pp. 33-41.

5. Vorobev, Yu.l. (Ed.). (1990) Kuznitsa inzhenernyih kadrov dlya morskogo flota (kratkiy istoricheskiy ocherk). Odessa: Moryak. (in Russian).

6. Moshnyanskij, A. (2001). Zvezda po imeni OIIMF. Izd. 2-e, dop. Odessa: Astroprint. (in Russian).

7. Odesskij nacional'nyj morskoj universitet: Istoriya. Lyudi. Sovremennost': 1930-2005. Odessa: Astroprint, 2005. (in Russian).

8. Malahov, V.P. (1995) Odesskij gosudarstvennyj politekhnicheskij universitet. Ocherki razvitiya nauki v Odesse / Otv. red. S.A. Andronati. Odessa: Titul, pp. 375-376.

9. Klark, CHarl'z Dzhonovich. Istoriya Odesskogo politekhnicheskogo v ocherkah / Yu.S. Denisov, V.I. Bondar'; pod red. V.P. Malahova. Odessa: Astroprint, 2000, pp. 35-38.

10. Klark, CHarl'z Dzhonovich. Istoriya Odesskogo politekhnicheskogo v ocherkah: 1918-2003 / Yu.S. Denisov, V.I. Bondar'; red. V.P. Malahov. Odessa: Astroprint, 2003, pp. 47-50.

11. Rikun, I.E. (2013) Klark Charlz Dzhonovich. EntsiklopedIya suchasnoyi Ukrayini, 13, 268.

12. Levchenko, V.V., Grivkivska, A.O., Shatalova, G.E. (2018). Profesor Ch.D. Klark - osnovopolozhnik vischoyi politehnichnoyi osviti v Odesi. Zbirnik prats XVI Mizhnarodnoyi molodizhnoyi naukovo-praktichnoyi konferentsiyi "Istoriya rozvitku nauki, tehniki ta osviti», prisvyachenoyi 120-richchyu Natsionalnogo tehnichnogo universitetu Ukrayini «Kiyivskiy politehnichniy Institut imenI Igorya Sikorskogo», 21-23.

13. Levchenko, V.V. (2010) Rozvitok merezhi naukovo-doslidnih ustanov Odesi v 1920-h rokah. Naukovi praci istorichnogo fakul'tetu Zaporiz'kogo nacional'nogo universitetu. Zaporizhzhya, vip. XXVIII, pp. 208-212. 
ВІСНИК

ОДЕСЬКОГО НАЦІОНАЛЬНОГО

МОРСЬКОГО УНІВЕРСИТЕТУ

№ 2 (62), 2020
HERALD

OF THE ODESSA NATIONAL

MARITIME UNIVERSITY

№ 2 (62), 2020

14. Levchenko, V.V. (2019) Iz istorii istokov stanovleniya i razvitiya vysshego morskogo obrazovaniya $v$ Odesse v pervoj polovine HKH veka. Visnik Odes'kogo nacional'nogo mors'kogo universitetu: Zb. nauk. prac', vip. 1 (58), pp. 249-265.

15. Levchenko, V.V. (2010) Istoriya Odes'kogo institutu narodnoï osviti (1920-1930 rr.): pozitivnij dosvid nevdalogo eksperimentu / Vidp. red. V.M. Hmars'kij; nauk. red. T.M. Popova. Odesa: TES. (in Ukrainian).

Стаття надійшла до редакиії 24.01.2020

Посилання на статтю: Левченко В.В., Левченко Г.С., Ляшенко А.Б. Перипетии судьбы профессора Чарльза Кларка: к истории «Одесского» периода жизни. Ч.1 // Вісник Одеського національного морського університету: Зб. наук. праць, 2020. № 2 (62). С. 7-28. DOI 10.47049/2226-1893-2020-2- 7-28.

Article received 24.01.2020

Reference a JournalArtic: Levchenko V., Levchenko G., Lyashenko A. The peripeties of professor Charles Clark: to the history of the «Odessa» period of life // Herald of the Odessa national maritime university. 2020. 2(62), 7-28. DOI 10.47049/2226-1893-2020-2-7-28. 